\title{
DEVELOPING A MECHANISM TO CUTTING GRASS IN PLUGS USED FOR TRANSPLANTING OPERATION.
}

\author{
S.H. Desoky* R.A. Wer by* A.K. Zaalouk**
}

\begin{abstract}
This research was carried out in order to develop a new sad cutting mechanism to cutt grass in plugs used for transplanting operation.

This was required to developing a traditional cutting mechanism, which is cutting the sod in slide rolls has $46 \mathrm{~cm}$ width.

The cutting knife is attached with some other perpendicular at $88 \mathrm{~mm}$ apart the cutting mechanism cuts and divided roll more smaller. The cutting is done in the two perpendicular direction to obtain slide plugs with $88 x 88 \mathrm{~mm}$ in dimension.

The cutting mechanism was made from high carbon steel.

The research was study the factor affecting the cutting mechanism as:

depth of cut, forward speed and edge, for three sod varieties, moisture content and knif cost operation on the quality of cut.

\section{The results obtain:}

The optimum forward speed was $22 \mathrm{~m} / \mathrm{min}$ gave the best quality at cutting depth of $4 \mathrm{~cm}$. The cutting quality was highly affected with the seeding edge and the best one was 90 days at 9\% moisture content. The productivity was about $0.12 \mathrm{fed} / \mathrm{h}$.
\end{abstract}

\section{INTRODUCTION}

he Egyptian government encourages increasing the turfgrass
areas. Which rapidly increased to serve tourists courts, new
tourists villages, clubs, hospitals, golf playgrounds and for special and public gardens.As the turfgrass decreases air pollution, the effect of sun radiation, and improves the environmental and weather conditions. Mechanical mechanizing and harvesting of the grass should be developed. On the other hand, the sod farms area in Egypt is may be extent.

\footnotetext{
* Assistant Prof. of Agr. Eng., Azhar Univ. ** Associt Prof. of Agr. Eng., Azhar Univ.
} 
As the turf grass became a profitable industry, the demand of turf grass areas and the turf grass production farms are rapidly increased, consequently; the requirement of sod cutting machines is also increased.

During the machine operation, the cutting mechanism is highly affected by the external forces due to the great variations of the soil resistance and also through the turfgrass roots resistance.

The $\boldsymbol{O M A F}$ (2003) reported that high quality of sod can be determined as follows:

1.Uniformity.

2.Good density.

3.Freedom from serious, weed seeds, diseases, insects and nematodes.

4.Acceptable color.

5.Adequate sod strength for handling.

6.Sufficient maturity in terms of carbohydrate reserves.

7.Minimal amount of thatch.

They reported that in considering resistances occurring in cutter bars, it is necessary to take into account:
a) Inertia of the knife bar,
b) Resistance of the crushed and cut material,
c) Frictional resistance of the knife bar,

Mabie and Reinholt, 1987 reborted, resistance of the crushed and cut plants depends on :
a) Rigidity of blades or stalks
b) Their thickness and moisture content,
c) Density of the growing plants,
d) Magnitude of feeding cutter bar, 
e) Technical conditions of the cutter bar and, in particular, on sharpness of the knife edges and the magnitude of clearance between the knife edges and counter-cutting edges.

Richey et al. (1961) reported that the factors affecting the capacity of field machine were as follows:

1. Operating width which affected by:

a) Measured width of machine.

b) Percentage of width actually used.

2. Speed of travel which affected by:

a) Draft of machine.

b) Drawbar power available.

c) Traction of power source.

d) Variations in grade and rolling resistance.

e) Operating limitations on speed such as quality work, ground roughness, obstacles, etc.

f) Percentage of non-operating time due to idle travel, such as traveling to field, turning at ends, etc.

The following factors are used for evaluating the sod cutting machine: (Desoky 2005)

1. Forward speed as affected by cutting depth.

2. Cutting quality as affected by cutting depth and forward speed.

3. Field capacity; and field efficiency.

4. Slip evaluation of the sod cutting machine.

5. Fuel consumption and energy requirement.

6. Productivity as affected by cutting depth and forward speed. 


\section{The following criteria was followed for developed sod cutting mechanism are very important:}

1- Simplicity of the design and construction.

2- The mechanism should be fabricated of local and available materials to minimize the cost.

3- Availability of spare parts.

4- Higher efficiency, durability and easily maintained.

This previous research was carried out in order to develop a new sod cutting mechanism to cutting grass in plugs and ,used for transplanting operation.

\section{MATERIALS AND METHODS}

\section{Material}

\section{Sod cutting machine construction: (Fig.1)}

The sod cutting machine was developed, constructed and evaluated in previous phD study for the first other, Desoky (2005).

The sod cutting machine constructed of the following:

Petrol engine, Power transmission system, Cutting mechanism, Frame, Steering hand and Wheels.

The engine power is transmitted through two pulleys made of cast iron; with $\mathrm{V}$ belt.

The cutting process is achieved through two modes of cutting, Fig. (2), shows the construction of the cutting system. The first mode is achieved by a horizontal knife which has $46 \mathrm{~cm}$ long, $6 \mathrm{~cm}$ wide and $0.6 \mathrm{~cm}$ thick. The second mode is achieved by horizontal knife which has two upper and one lower angles namely: frontal clearance, rake and bottom clearance angels. The frontal clearance and rake angles are inclined by $45^{\circ}$ and $75^{\circ}$ with the horizontal respectively. The frontal clearance angle reduces the knife area of contact; also the rake angle helps in raking the cutting area. The lower one is the bottom clearance angle that reduces the friction during the cutting process. It has a tilt angle of $15^{\circ}$ with the horizontal plane from the bottom of the knife. 


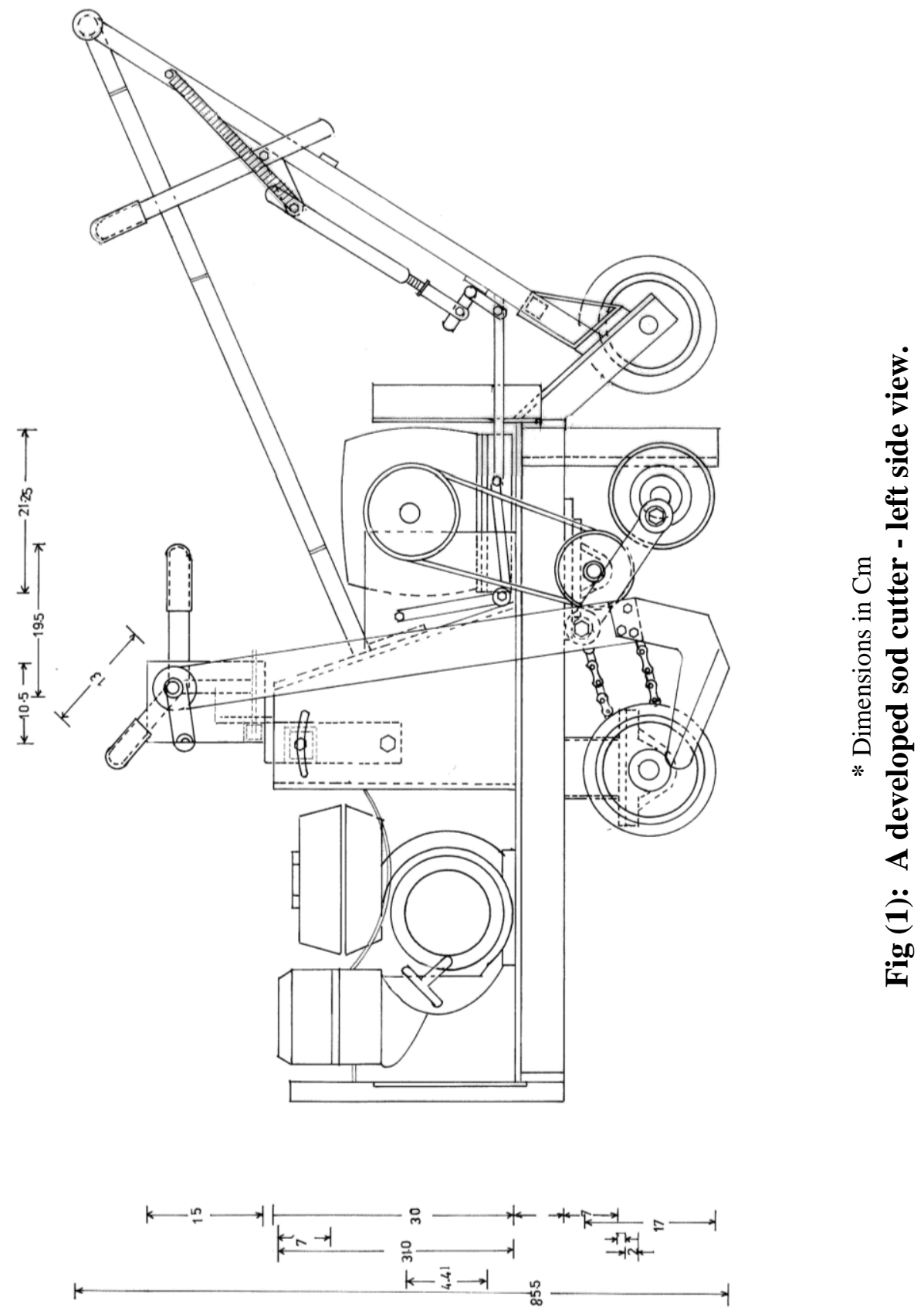




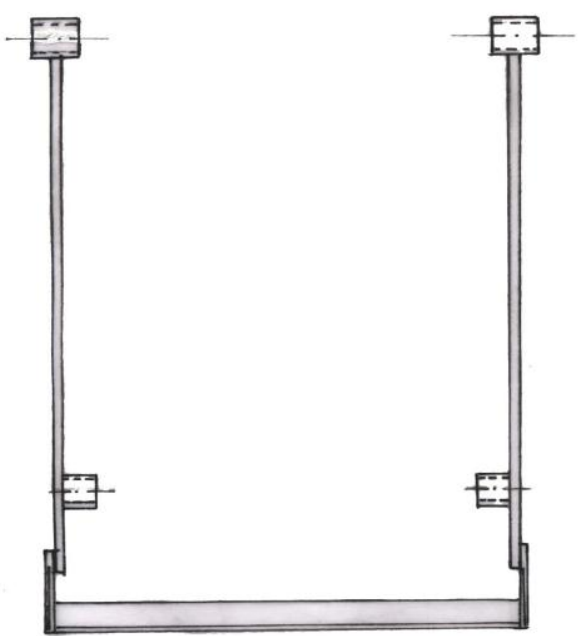

Elevation

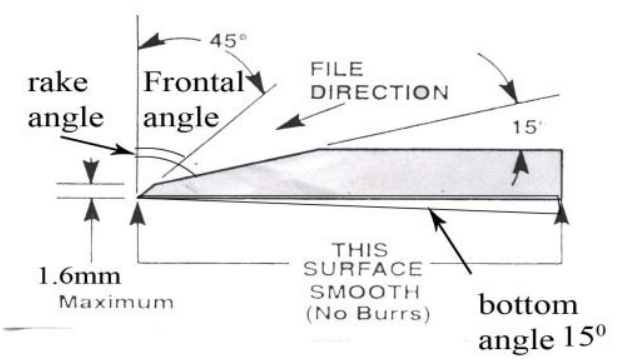

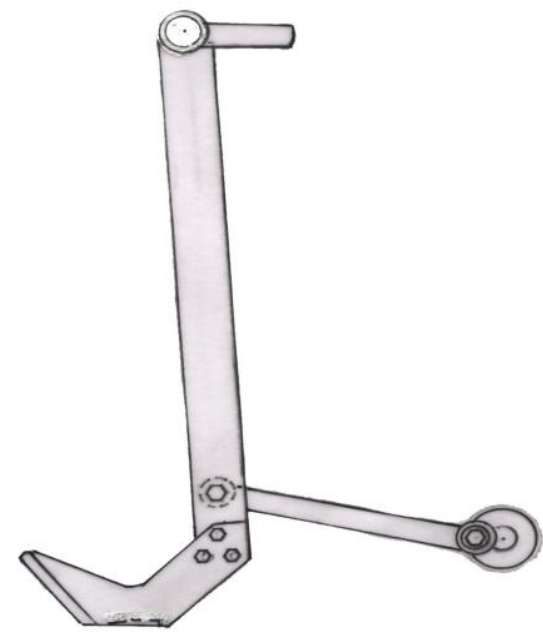

Side View

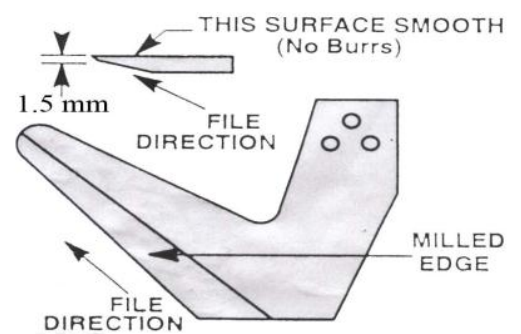

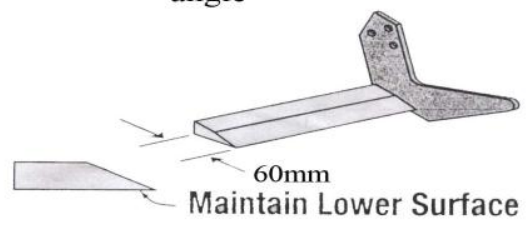

Fig (2) Construction of the ordinary cutting system (before the developing)

\section{The Ordinary cutting system}

This research was carried out in order to develop a new sad cutting mechanism to cutt grass in plugs used for transplanting operation.

This was required to developing a traditional cutting mechanism, which is cutting the sod in slide rolls has $46 \mathrm{~cm}$ width.

The developing mechanism to cutting grass plugs to transplanting operation: (Fig.3)

This research was carried out in order to develop a new sad cutting mechanism to cut grass in plugs used for transplanting operation. 
This was required to developing a traditional cutting mechanism, which is cutting the sod in slide rolls has $46 \mathrm{~cm}$ width.

The cutting knife is attached with some other perpendicular at $88 \mathrm{~mm}$ apart the cutting mechanism cuts and divided roll more smaller. The cutting is done in the two perpendicular direction to obtain slide plugs with $88 x 88 \mathrm{~mm}$ in dimension.

The cutting mechanism was made from high carbon steel.

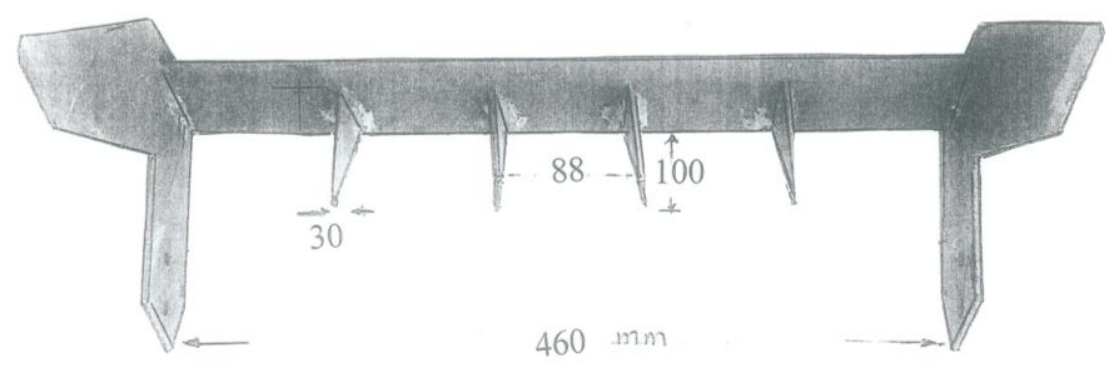

Fig(3): The developing mechanizem to cutting grass plugs used to transplanting operation

\section{b. The frame:}

The frame is constructed of rectangular L-shape steel sections $50 \times 50 \times 10$ $\mathrm{mm}$ lying horizontally. Two inclined vertically squared tubes were welded as trapezoidal shape to the frame, and a horizontal circular tube section of the length of handle is $750 \mathrm{~mm}$ is welded to them as a steering handle of the machine.

The engine and gearbox are assembled to the machine frame by rectangular- shape steel sheet of $22.5 \mathrm{~cm}$ long, $20.5 \mathrm{~cm}$ wide and $0.3 \mathrm{~cm}$ thick is welded horizontally to the frame. The frontal plate is vertically welded $31.5 \mathrm{~cm}$ long and $20.5 \mathrm{~cm}$ wide. The back side is inclined to the vertical with an angle $60^{\circ}$. The two sides form two similar trapezoids. The large base is $24.5 \mathrm{~cm}$ and the smallest is $14 \mathrm{~cm}$. The two other dimensions were $31.5 \mathrm{~cm}$ and $35 \mathrm{~cm}$. The left and right sides have two grooves used 
for controlling the cutting depth through pitch adjustment. The two ground wheels are attached to the frame .

A large T shape hand is used to steer the sod cutter. Steering handles are also used for controlling the fuel by a twisting grip accelerator.

\section{Turfgrass varieties}

Turfgrass varieties were used in the present study namely: Pasplum, Tifway and tifgreen. These are commonly used in Egypt.

\section{Soil analysis}

The partial size distribution of soil prevailed in the sod farm was textural loamy sand soil of $86.3 \%$ sand, silt $6.3 \%$, and $7.4 \%$ clay, bulk density $1.64 \mathrm{~g} / \mathrm{cm}^{3}$, saturation hydraulic conductivity $4.78 \mathrm{~cm} /$ hour, available water $0.08 \mathrm{~cm}^{3}$ water $/ \mathrm{cm}^{3}$ soil.

\section{Methods}

1. Forward speed as affected by cutting depth for the three different turfgrass varieties

The effect of cutting depth on the forward speed for three different varieties were studied. Ten cutting depths namely : 1,2,3,4,5,6,7,8,9, and $10 \mathrm{~cm}$ were studied for the three varieties tested.

2. Productivity as affected by cutting depths and forward speed for the three different varieties

Productivity of sod cutting machine was evaluated as the ratio of sod cutting area and elapsed time. Productivity $\mathrm{m}^{2} / \mathrm{h}$ was evaluated as affected by the forward speed $\left(\mathrm{m}^{2} / \mathrm{h}\right)$ and the cutting depths for the three different sod ages and the three varieties tested.

3. Cutting quality as affected by cutting depths and forward speeds at three different turf grass ages of Pasplum, tifway and tifgreen

The cutting quality is evaluated based on area of $0.5 \mathrm{~m}^{2}$ of sod cutting roll. The loss is evaluated as area of sod without soil to the total roll area as follows:

Cutting quality $=($ total area of roll - loss $) /$ total area 
Cutting quality was evaluated as affected by the cutting depths, turf age and turf varieties.

\section{Cost analysis:}

The cost analysis was evaluated according to Awady (1978) equation.

\section{RESULT AND DISCUSSIONS}

\section{Field capacity, and field efficiency}

The actual field capacity was determined .Actual field capacity was 607.2 $\mathrm{m}^{2} / \mathrm{h}$. The field efficiency was also evaluated which was $91 \%$. The field efficiency for cutting sod was large in magnitude which can be interpreted by small time consumed for turning and also long cutting distances without turning.

\section{Forward speed of machine as affected by the cutting depths for three different sod varieties}

The effect of cutting depths on the forward speed of the cutting machine, For three different levels of moisture content \% dry basis namely: 9.46, 9.08 and 7.05, and for three different grass ages of 80, 90 and 100 days after transplanting the sod are presented in Figs (4). It was found that as the sod age increases the forward speed decreases for all varieties tested and for cutting depths ranging from $10 \mathrm{~mm}$ to $100 \mathrm{~mm}$. This can be interpreted as the longer the sod age the higher the sod resistant to cut and accordingly decrease in forward speed at maximum machine power. On the other hand, as the moisture content of the sod decreases, the sod resistance to cut increases. This may be related to the increase of friction and resistance of soil.

\section{Productivity of machine as affected by the cutting depths and Forward speed}

Figs (5) shows that as the sod age increases the productivity of the cutting machine decreases, and also, as the moisture content decreases the cutting productivity decreases. 
4. Cutting quality of machine as affected by the cutting depths and Forward speed

The quality of the roll of the sod cutting machine was evaluated $\mathrm{m} 2 / \mathrm{h}$ as mentioned in the previous chapter. Showed that as the sod age increases the quality of roll increases and also the deeper the cutting depth the higher the quality of cut. This fact is true but, it is not recommended to cut the sod deeply. The deep cut is a disadvantage to breading farms and consumes more power and fuel.

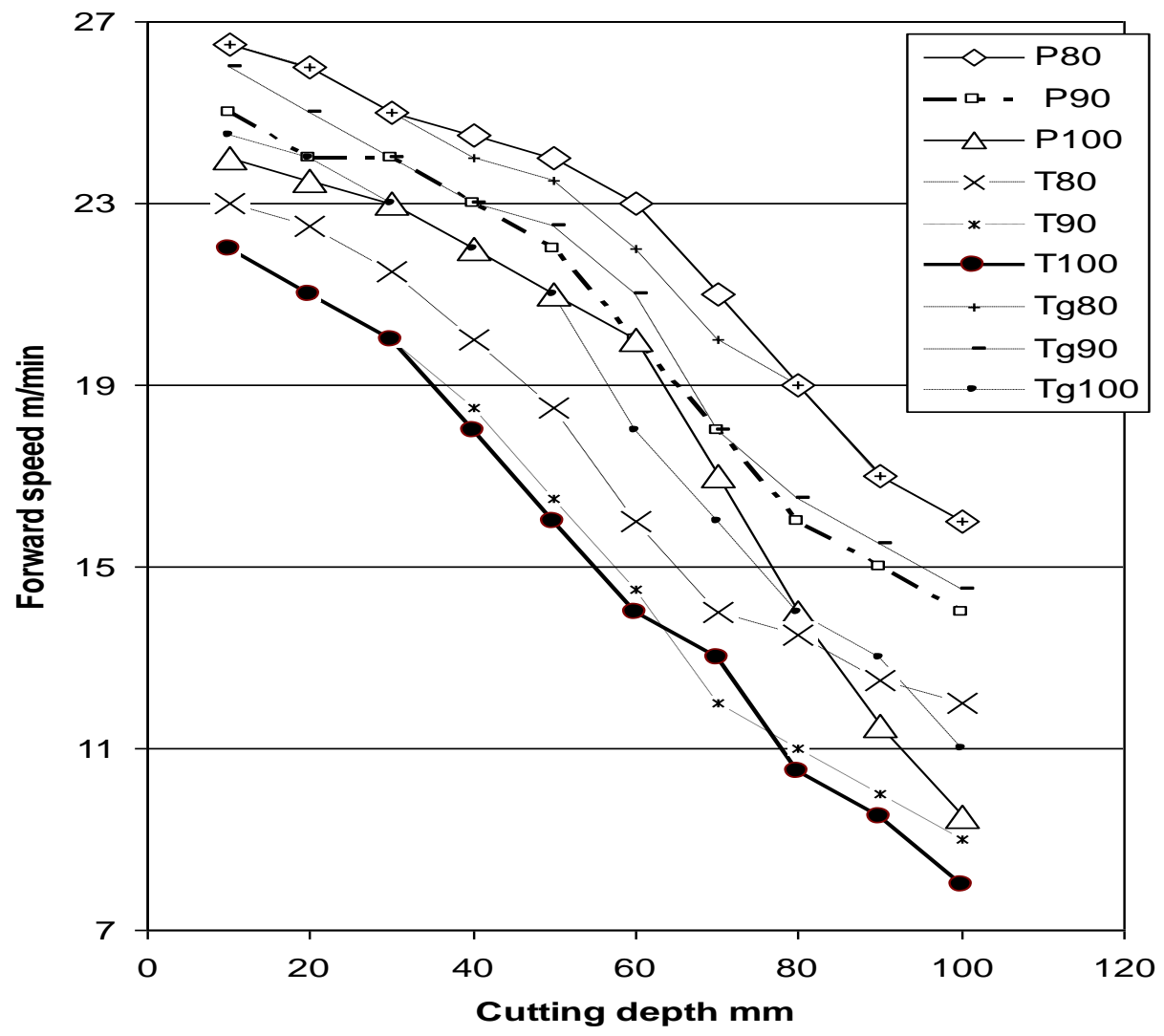

Fig.(4) The effect of cutting depth on the machine forward speed with an average moisture content of $9.46 \%$ dry basis and three different grass varieties. 


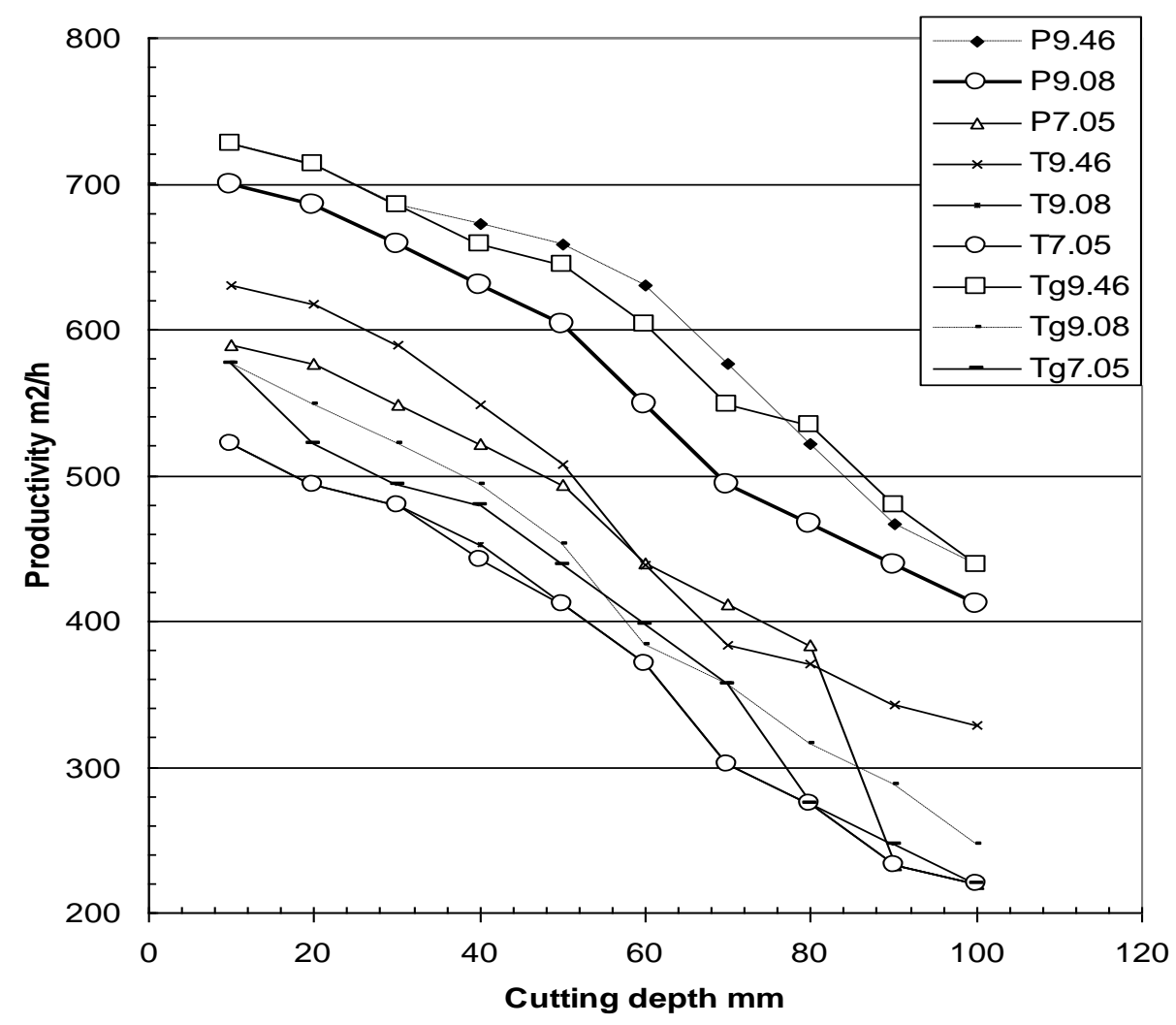

Fig.(5): The effect of the cutting depth on the machine productivity with average moisture contents of $9.46,9.08$ and 7.05 for all varieties and grass age of 80 days old.

Table (1):The effect of the cutting depth $(\mathrm{mm})$ on the quality at an average moisture content of 9.46, 9.08 and $7.05 \%$ dry basis for all grass varieties and grass age of 80 days after transplanting sod.

\begin{tabular}{|c|c|c|c|c|c|c|c|c|c|}
\hline Variable & \multicolumn{9}{|c|}{ Sod cutting quality } \\
\hline Turf variety & \multicolumn{3}{|c|}{ Pasplum } & \multicolumn{3}{c|}{ Tifway } & \multicolumn{3}{c|}{ Tifgreen } \\
\hline Mc & $\mathbf{9 . 4 6}$ & $\mathbf{9 . 0 8}$ & $\mathbf{7 . 0 5}$ & $\mathbf{9 . 4 6}$ & $\mathbf{9 . 0 8}$ & $\mathbf{7 . 0 5}$ & $\mathbf{9 . 4 6}$ & $\mathbf{9 . 0 8}$ & $\mathbf{7 . 0 5}$ \\
\hline Cutting depth & & & & & & & & & \\
\hline 10 & 20.0 & 3.0 & 3.5 & 5.0 & 5.0 & 3.5 & 4.0 & 3.0 & 3.5 \\
\hline 20 & 35.0 & 20.0 & 22.0 & 25.0 & 31.0 & 30.0 & 25.0 & 22.0 & 3350.0 \\
\hline 30 & 70.0 & 32.0 & 28.0 & 38.0 & 37.0 & 34.0 & 35.0 & 30.0 & 95.0 \\
\hline 40 & 100.0 & 68.0 & 86.0 & 100.0 & 100.0 & 90.0 & 85.0 & 70.0 & 100.0 \\
\hline 50 & 100.0 & 73.0 & 100.0 & 100.0 & 100.0 & 100.0 & 100.0 & 95.0 & 100.0 \\
\hline 60 & 100.0 & 74.0 & 100.0 & 100.0 & 100.0 & 100.0 & 100.0 & 100.0 & 100.0 \\
\hline 70 & 100.0 & 74.0 & 100.0 & 100.0 & 100.0 & 100.0 & 100.0 & 100.0 & 100.0 \\
\hline 80 & 100.0 & 74.0 & 100.0 & 100.0 & 100.0 & 100.0 & 100.0 & 100.0 & 100.0 \\
\hline 90 & 100.0 & 74.0 & 100.0 & 100.0 & 100.0 & 100.0 & 100.0 & 100.0 & 100.0 \\
\hline 100 & 100.0 & 74.0 & 100.0 & 100.0 & 100.0 & 100.0 & 100.0 & 100.0 & 100.0 \\
\hline
\end{tabular}




\section{REFRENCES}

Awady ,M.N. (1978) .Tractors and farm machinery Text book,col. Of Agr. Ain Shams U.

Desoky, S.H. 2005, Development of Sod cutter P.H.D Thisis ,Agr.Eng. Azhar Univ.

Mabie H.H. and C.F., Reinholtz (1987) Mechanisms and dynamics of machinery, John Wiley and Sons.N.Y.:35-89.

OMAF (2003) :http// www.gov.on.ca/ OMAA FRA / into so dpro.

الملخص العربي

\section{تطوير آلية لتقطيع غرس النجيل لاستخدامه فى الشتل}

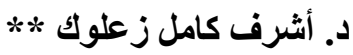

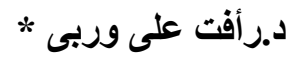

* د. سمير حافظ دسوقى

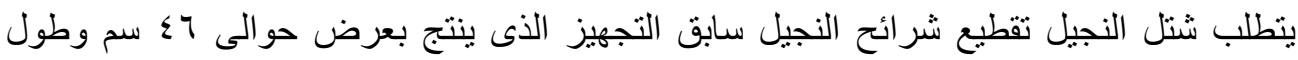

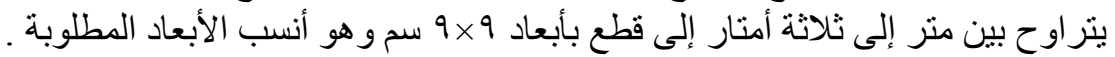

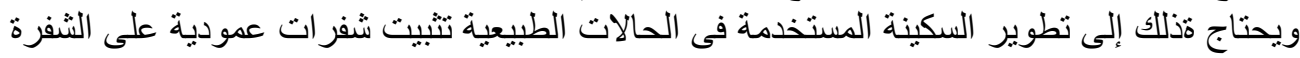

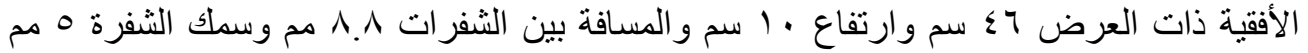

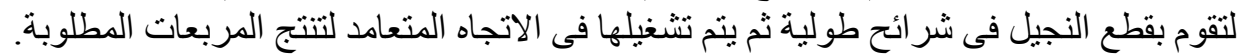

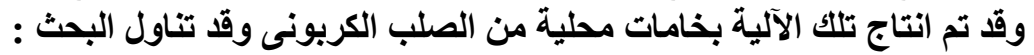

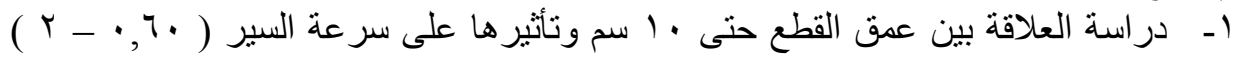
كم/س وكفاءة القطع .

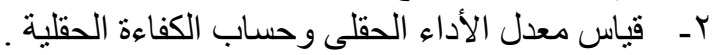

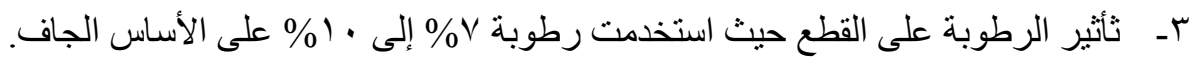

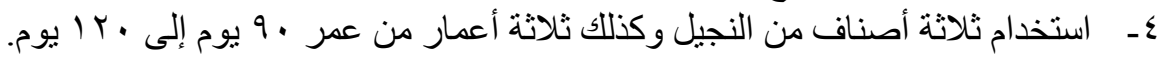

- تقل سرعة القطع بكبر عمر النبات للأصناف المختلفة وتقل أيضا بزيادة عمق القطع و و أفضل سر عة كانت . r م / د. د. -

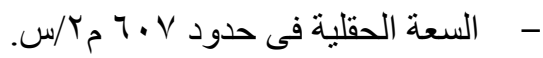

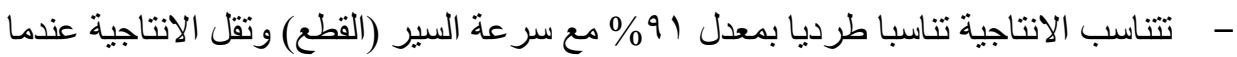

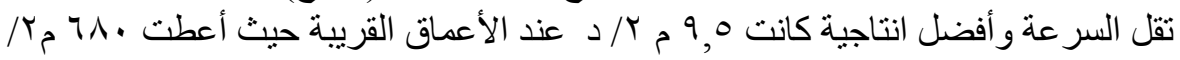

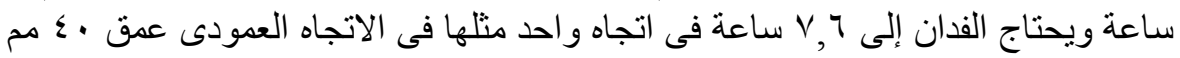

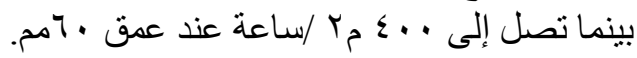

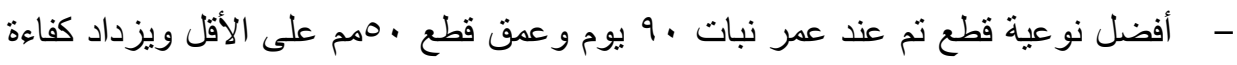

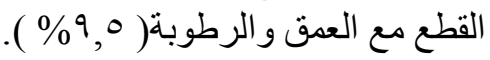

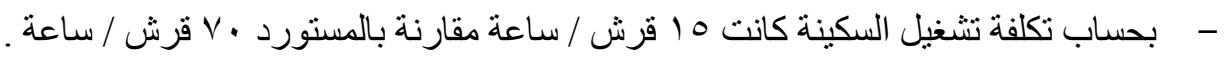
*مدرس، ** أستاذ مساعد بكلية الهندسة الزراعية - جامعة الأزهر - القاهرة. 